\title{
THE USE OF FOREIGN WORDS FROM TRANSPORT PUBLICATIONS OF THE END OF THE 19TH CENTURY AND THE FIRST HALF OF THE 20TH CENTURY
}

\author{
Angelika PETRÉTIENÉ \\ Division of Lithuanian Language, Vilnius Gediminas Technical University, Vilnius, Lithuania
}

Received 2 March 2017; revised 30 May 2017; accepted 1 October 2017

\begin{abstract}
The article analyses foreign words (their origin, meaning and equivalents), selected from the transport publications of the end of the 19th century and the first half of the 20th century: the conducted questionnaire method assesses the relevancy of foreign words nowadays, i.e. whether the respondents are aware of the equivalents of foreign words, as well as examines the usage frequency of foreign words. The research defines the respondents' attitudes towards changing foreign words into their equivalents. It also examines the current usage of the foreign words in different language functional styles. The results of the research are structured and provided in the table and figures.
\end{abstract}

Keywords: transport terms, questionnaire method, foreign words, equivalents, respondents, origin of the foreign words.

"The use of foreign words is as old, vibrant and relevant, as the language of our papers itself"

P. Skardžius

\section{Introduction}

Talking about the usage of foreign words during the period of the eighth decade of the 19th century and the end of the fourth decade of the 20th century, Z. Zinkevičius (1992) emphasized the importance and relevancy of the language purification. It was necessary to approve the correct application of some foreign words, as well as to eliminate and replace some foreign words by their native equivalents. At first, they had to examine all loanwords, existing in the Lithuanian language. K. Būga provided the basis for the loanwords investigation, contributing a lot to this area of research. P. Skardžius continued his work, compiling a dictionary of Slavic loanwords used in the old papers. K. Alminauskis (Alminas) examined and registered German loanwords, publishing their dictionary in 1935. These and other works influenced better differentiation of loanwords and establishment of their status in the official language (Zinkevičius 1992).

J. Šlapelis (1907) "Dictionary of alien and incomprehensible words" (Svetimu ir nesuprantamu žodžiu žodynelis), published in Tilže in 1907, is the first work of
Lithuanian lexicography, systematically managing words of foreign origin (transport, economy and management terms are found in this dictionary as well as in other further mentioned sources) (i.e.: benzinas (benzine), cilindras (cylinder), transportas (transport), etc.). "Dictionary of alien and international words" (Svetimu ir tarptautišku žodžiu žodynèlis) compiled by M. and S. (M. ir S. 1923), in Šiauliai (i.e.: motoras (motor), navigacija (navigation), tranzitas (transit), etc.), and "Dictionary of alien and incomprehensible words" (Svetimu ir nesuprantamu žodžiu žodynèlis), compiled by J. Norkus (1924), in Kaunas (i.e.: instruktorius (instructor), mechanizmas (mechanism), etc.). "Dictionary of international words" (Tarptautiniu žodžiu žodynas) (Boruta et al. 1936) is the first Lithuanian dictionary of international words (i.e.: avarija (accident), ekonomika (economics), karbiuratorius (carburetor), etc.).

This article investigates students' usage of foreign words from transport publications of the end of the 19th century and the first half of the 20th century.

The aim of the article is: to present foreign words from the publications under discussion.

The ultimate goals are:

1. To determine the origin and value of foreign words.

2. To investigate the level and frequency of usage of foreign words in students' speech.

3. To reveal students' attitudes towards changing foreign words into their equivalets.

${ }^{*}$ Corresponding author. E-mail: angelika.petretiene@vgtu.lt 
The dictionaries of the first half of the 20th century (Table 2) also contained the foreign words, selected from the analysed sources. Some of the explanations of foreign words, such as ketvirtis (quarter), statine (barrel), keleivis (passenger), (geležinkelio) bègiai (rails), plentas (highway) over time changed foreign words, becoming special terms themselves. The foreign words pasažieras, šosiejai, šosieja in the dictionaries of that time differ in their grammatical form from those found in the transport sources (Table 2). By analysing the international terms of Fizika by I. Končius (1919), A. Kaulakienè (2009) pointed out that "part of them have slightly different phonetic or morphological form, which is not quite common nowadays, for example: aluminijus (aluminium); amplituda (amplitude) $<\ldots$.. " (Končius 1919). This is typical of the Lithuanian terms, found in the older sources and at different periods, for example: atspindis (=atspindys) (reflection), duja (=dujos) (gas) (Končius 1919; Kaulakienè 2009); velènas (=velenas) (shaft), žvaki (=žvakess) (plugs) (KAM 1919; Petrètienè, Tomaševskis 2011).

In order to determine the popularity of foreign words and their survival in the current students' speech, the respondents answered the following guestions: "What equivalents do you use for the presented words?" and "Do you often use the presented words?" Table 2 shows the statistical data of the research. The results of the first question are arranged in the descending order, highlighting in bold the exact equivalents of foreign words.

There is a list of old foreign words in the book "Lexis: the usage of loanwords" (Leksika. Skoliniu vartojimas) from "Language advices" (Kalbos patarimai), published in 2013 (Mikulèniené, Dvylyte 2013), with only two foreign words from Table 1 - adyna, risorai (resorai - KAM (1919)). The results of the research suggest that these foreign words are still known (Table 2): $38.4 \%$ of the respondents indicated the exact equivalents valanda (hour), 19.2\% linges (springs).

There are words of hybrid formation in Olševskis (1899): pusadinis, adynèle: Čia jau trukis ant pusadinio susiturejo (The train was delayed for half an hour). Adynele praejo - vel atsiliepé švilpikas, trukis stabdytis prasidejo ir ant keleto minutu ant stacijos apsistojo (An hour passed, after the repeated whistle the train started to brake and in several minutes it stopped at the station).

The foreign word resorai in KAM (1919) is used interchangeably as lingines, indicating the same item and originating from the Samogitian dialect, but not becoming a term of transport, i.e.: Prireikus ilga laika važinèti blogais keliais lingines patartina sandariai apvynioti virvemis (If necessary to drive on bad roads for a long time, it is advisable to wind up the springs tightly by ropes).

The data from Table 2 show that $23.3 \%$ of the respondents know the equivalent of tavorai, in the meaning of prekes (goods) (the respondents also indicated words of close meaning: produktai (products), pirkiniai (purchase). The popularity of the foreign word tavorai in the proverbs and other poetical works of Lithuanian folklore, could possibly make the great influence for its survival:

Kas pejk sawa tawora; tan isz turgaus wara (The person who speaks badly about his own goods, is sent away from the market) (Valančius 1867). Geras tavoras pats apie save $k a l b a$ (Qualitative goods are praising themselves) (Bufienè et al. 2008).

Mano tavoras žemiškas, žmonems pažadètas; Iš duonos ir druskos paprastai sudetas <.... (My goods are worldly, and intended for people; formed from bread and salt $<. . .>$ ) (Trys Telšiu kepyklos 1931).

The introduction of "Language advices" (Mikulèniené, Dvylyte 2013) states, that "in some cases, the old foreign words can be considered as words, identifying national heritage units, objects or products. As a potential stylistic means, they can be used in the texts of publicistic or artistic styles".

The results of the research show that the respondents know foreign word bosas, as a loanword, defining a man in the leading position, (46.6\% as viršininkas (head), $31.5 \%$ as vadovas (manager), $11 \%$ as direktorius (director). Such equivalents of foreign word are specified in "Language advices" (Mikulèniené, Dvylytė 2005) as viršininkas (head), vadovas (manager), šefas (chief). The examples from other publications of that period prove the fact that during that period of time, foreign word bosas had this meaning, as well as the meaning of the barrel (statine, kubilas): Amerika ligi tol nežinojo apie Lietuva ir lietuvius, nebent kur kokioj dirbtuvej „, bosas" težinojo lietuvius kaipo gerus darbininkus $<\ldots>$ (Hitherto in America nobody knew about Lithuania or Lithuanians, unless "the boss" of the manufactory knew Lithuanians as good workers $<\ldots . .>$ ) (Nedarykite, kas nedarytina 1924). <...> laivas prisikrove kelis bosus labai pavojingu duju (fosgeno) ir išplauke i jüra (<...> the ship filled up several tubs with very dangerous gases (phosgene) and left) (Negyvujuc laivas 1932).

Even $68.5 \%$ of respondents indicated the exact equivalent keleivis (passenger) of the foreign word pasažieras. Examples of both sources - transport publications and the periodicals, show that the word keliauninkas, meaning "somebody travelling or walking" (Keinys 2012) was also used during that period of time, i.e.: Automobilio begimo greitumas priguli nuo kelio paviršiaus, oro, dienos laiko, keliauninku daugumo ir $t$. $t$. (The speed of a vehicle depends on the road surface, weather, time of day, number of passengers, etc.) (KAM 1919). Tame laike visai sutemo; keliauninkai pradējo lipti nů lubu; o ant laivo pakilo didelē sumata (At that time it became dark; the passengers started to descend from the deck and complete night fell on the ship) (Milcziauckas 1886).

The statistical data of the research show that 32.9\% of respondents know the foreign word rulis as a "steering wheel". It is likely that the Russian language word руль, originating from the Dutch language, influenced the fact. The Boruta et al. (1936) describes this foreign word in the same way, while in KAM (1919) this word means "cylinder" (cilindras) (for comparison: Petretienè, Tomaševskis 2011). 
Table 2. The research data of the usage of foreign words and their popularity (items, percentage)

\begin{tabular}{|c|c|c|c|}
\hline $\begin{array}{l}\text { Foreign words, meaning in the } \\
\text { dictionaries of the first part of the } \\
\text { 20th century }\end{array}$ & \multicolumn{2}{|c|}{ "What equivalents do you use for the presented words?" } & $\begin{array}{l}\text { "Do you often } \\
\text { use the presented } \\
\text { words?" }\end{array}$ \\
\hline adyna & \multicolumn{2}{|l|}{$\begin{array}{l}\text { not specified } 43(58.9 \%) \\
\text { valanda (hour) } 28(38.4 \%) \\
\text { vienas (one) } 1(1.4 \%) \\
\text { vienetas (one) } 1(1.4 \%)\end{array}$} & $\begin{array}{l}\text { often } 1(1.4 \%) \\
\text { rarely } 5(6.8 \%) \\
\text { never } 67(91.8 \%)\end{array}$ \\
\hline $\begin{array}{l}\text { bertainis } \\
\text { bertainis - a quarter, čvertis } \\
\text { (Šlapelis 1907) }\end{array}$ & \multicolumn{2}{|l|}{$\begin{array}{l}\text { not specified } 70(95.9 \%) \\
\text { ketvirtis (quarter)1 }(1.4 \%) \\
\text { ketvirtadalis (guarter) } 1(1.4 \%) \\
\text { rite (coil) } 1(1.4 \%)\end{array}$} & $\begin{array}{l}\text { often } 0(0 \%) \\
\text { rarely } 0(0 \%) \\
\text { never } 73(100 \%)\end{array}$ \\
\hline blèta & $\begin{array}{l}\text { not specified } 56(76.7 \%) \\
\text { skarda (sheet) 11 (15\%) } \\
\text { sena moteris (old woman) } 2(2.7 \%) \\
\text { boba (woman) 1 (1.4\%) }\end{array}$ & $\begin{array}{l}\text { keptuve (frying pan) } 1(1.4 \%) \\
\text { padeklas (tray) } 1(1.4 \%) \\
\text { bleka (sheet) } 1(1.4 \%)\end{array}$ & $\begin{array}{l}\text { often } 0(0 \%) \\
\text { rarely } 9(12.3 \%) \\
\text { never } 64(87.7 \%)\end{array}$ \\
\hline $\begin{array}{l}\text { bosas } \\
\text { bosas - barrel (Šlapelis 1907) } \\
\text { bosas - I. The lowest masculin } \\
\text { voice; } 2 \text {. The lowest main tone of } \\
\text { an accordion; 3. barrel (Boruta et } \\
\text { al. 1936) } \\
\text { bosas [angl. boss] - 1) the } \\
\text { owner or head of an enterprise } \\
\text { (Lemchenas 1951) }\end{array}$ & $\begin{array}{l}\text { not specified } 4(5.5 \%) \\
\text { viršininkas (head) } 34(46.6 \%) \\
\text { vadovas (manager) } 23(31.5 \%) \\
\text { direktorius (director) } 8(11 \%)\end{array}$ & $\begin{array}{l}\text { šefas (chief) } 2(2.7 \%) \\
\text { muzikos instrumentas (musical } \\
\text { instrument) } 1(1.4 \%) \\
\text { indas skystai medžiagai (a vessel } \\
\text { for fluid storage) } 1(1.4 \%)\end{array}$ & $\begin{array}{l}\text { often } 22(30.1 \%) \\
\text { rarely } 42(57.5 \%) \\
\text { never } 9(12.3 \%)\end{array}$ \\
\hline karbas & $\begin{array}{l}\text { not specified } 36 \text { ( } 49.3 \%) \\
\text { karbiuratorius (carburetor) } \\
23(31.5 \%) \\
\text { krepšys (bag) } 6(8.2 \%) \\
\text { degalu dozatorius (fuel batcher) } \\
2 \text { (2.7\%) } \\
\text { garintuvas (evaporator) } 1(1.4 \%)\end{array}$ & $\begin{array}{l}\text { pintinis krepšys (braided bag) } 1 \\
(1.4 \%) \\
\text { išsikišimas (protrusion) } 1(1.4 \%) \\
\text { maitinimo sistema (fuel supply } \\
\text { system) } 1(1.4 \%) \\
\text { iškili, atsikišusi dalis (protruding } \\
\text { part) } 1 \text { (1.4\%) } \\
\text { protektorius (protector) } 1(1.4 \%)\end{array}$ & $\begin{array}{l}\text { often } 9(12.3 \%) \\
\text { rarely } 17(23.3 \%) \\
\text { never } 47(64.4 \%)\end{array}$ \\
\hline $\begin{array}{l}\text { kerneris } \\
\text { kerneris - plater - equipment } \\
\text { in metalsmithing, i. e. a sharp } \\
\text { steal tine for marking dots while } \\
\text { marking details (Lemchenas 1951) }\end{array}$ & $\begin{array}{l}\text { not specified } 68(93.2 \%) \\
\text { žymeklis (plater) } 2(2.7 \%) \\
\text { irankis (tool) } 1(1.4 \%)\end{array}$ & $\begin{array}{l}\text { padavejas (waiter)1 } 1(1.4 \%) \\
\text { apykaklè (collar) } 1(1.4 \%)\end{array}$ & $\begin{array}{l}\text { often } 1(1.4 \%) \\
\text { rarely } 0(0 \%) \\
\text { never } 72(98.6 \%)\end{array}$ \\
\hline kreismeselis & \multicolumn{2}{|l|}{$\begin{array}{l}\text { not specified } 71(97.3 \%) \\
\text { durtuvas (bayonet) } 1(1.4 \%) \\
\text { peilis (knife) } 1(1.4 \%) \\
\end{array}$} & $\begin{array}{l}\text { often } 0(0 \%) \\
\text { rarely } 0(0 \%) \\
\text { never } 73(100 \%)\end{array}$ \\
\hline naždako popierius & $\begin{array}{l}\text { not specified } 41(56.2 \%) \\
\text { švitrinis popierius (abrasive } \\
\text { paper) } 24(32.9 \%) \\
\text { šlifavimo popierius (buffing } \\
\text { paper) } 5(6.8 \%)\end{array}$ & \begin{tabular}{|l|} 
skolos raštas (debt paper) 1 (1.4\%) \\
abrazyvinis popierius (abrasive paper) \\
$1(1.4 \%)$ \\
šveičiamasis popierius (abrasive \\
paper) $1(1.4 \%)$
\end{tabular} & $\begin{array}{l}\text { often } 5(6.8 \%) \\
\text { rarely } 12(16.4 \%) \\
\text { never } 56(76.7 \%)\end{array}$ \\
\hline $\begin{array}{l}\text { pasažieras } \\
\text { pasažeras - passenger, travelling } \\
\text { by railway or a steamboat (Šlapelis } \\
\text { 1907); pasažierius - passenger, } \\
\text { travelling by train or other means } \\
\text { of travelling, paying for the trip } \\
\text { (Boruta et al. 1936) }\end{array}$ & \multicolumn{2}{|l|}{$\begin{array}{l}\text { not specified } 20(27.4 \%) \\
\text { keleivis (passenger) } 50(68.5 \%) \\
\text { padejejas (assistant) } 1(1.4 \%) \\
\text { vairuotojas (driver) } 1(1.4 \%) \\
\text { palydovas (attendant) } 1(1.4 \%)\end{array}$} & $\begin{array}{l}\text { often } 3(4.1 \%) \\
\text { rarely } 7(9.6 \%) \\
\text { never } 63(86.3 \%)\end{array}$ \\
\hline $\begin{array}{l}\text { relsai } \\
\text { relsai - railway rails (Boruta et al. } \\
1936 \text { ) }\end{array}$ & \multicolumn{2}{|c|}{$\begin{array}{l}\text { not specified } 46(63 \%) \\
\text { (geležinkelio) bégiai (railway rails) } 24(32.9 \%) \\
\text { geležinkeliai (railways) } 2(2.7 \%) \\
\text { reisas (trip) } 1(1.4 \%)\end{array}$} & $\begin{array}{l}\text { often } 5(6.8 \%) \\
\text { rarely } 4(5.5 \%) \\
\text { never } 64(87.7 \%)\end{array}$ \\
\hline $\begin{array}{l}\text { resorai } \\
\text { resorai - springs in a carriage, } \\
\text { vehicle, etc. (Boruta et al. } 1936 \text { ) }\end{array}$ & $\begin{array}{l}\text { not specified } 53(72.6 \%) \\
\text { lingès (springs) } 14(19.2 \%) \\
\text { resursai (resources) } 4(5.5 \%)\end{array}$ & $\begin{array}{l}\text { rezervai (reserves) } 1(1.4 \%) \\
\text { peiliai (knives) } 1(1.4 \%)\end{array}$ & $\begin{array}{l}\text { often } 6(8.2 \%) \\
\text { rarely } 4(5.5 \%) \\
\text { never } 63(86.3 \%)\end{array}$ \\
\hline
\end{tabular}


End of Table 2

\begin{tabular}{|c|c|c|c|}
\hline \multirow{2}{*}{$\begin{array}{l}\text { Foreign words, meaning in the } \\
\text { dictionaries of the first part of the } \\
\text { 20th century }\end{array}$} & \multicolumn{2}{|c|}{ "What equivalents do you use for the presented words?" } & \multirow{2}{*}{\begin{tabular}{|c}
$\begin{array}{c}\text { "Do you often } \\
\text { use the presented } \\
\text { words?" }\end{array}$ \\
\\
often $7(9.6 \%)$ \\
rarely $6(8.2 \%)$ \\
never $60(82.2 \%)$
\end{tabular}} \\
\hline & $\begin{array}{l}\text { not specified } 35(47.8 \%) \\
\text { vairas (steering wheel) } 24(32.9 \%) \\
\text { rulonas (roll) } 3(4.1 \%) \\
\text { ritinys (roll) } 2(2.7 \%) \\
\text { volas (roller) } 2(2.7 \%) \\
\text { šiaudu ritinys (a roll of } \\
\text { straw) } 1(1.4 \%)\end{array}$ & $\begin{array}{l}\text { kočélas (rolling pin) } 1(1.4 \%) \\
\text { šieno ritinys (a roll of hay) } 1(1.4 \%) \\
\text { šieno rulis (a roll of hay) } 1(1.4 \%) \\
\text { velenas (shaft) } 1(1.4 \%) \\
\text { volelis (roller) } 1(1.4 \%) \\
\text { rité (coil) } 1(1.4 \%)\end{array}$ & \\
\hline $\begin{array}{l}\text { stacija } \\
\text { [lat. statio "habitation"] - the } \\
\text { habitation place used by an animal } \\
\text { or animal species constantly or for } \\
\text { a specified function (Lemchenas } \\
\text { 1951) }\end{array}$ & $\begin{array}{l}\text { not specified } 55(75.3 \%) \\
\text { stotis (station) } 8(11 \%) \\
\text { situacija (situation) } 3(4.1 \%) \\
\text { stotele (stop) } 3(4.1 \%)\end{array}$ & $\begin{array}{l}\text { paveikslas (picture) } 2(2.7 \%) \\
\text { straipsnis (article) } 1(1.4 \%) \\
\text { radijas (radio) } 1(1.4 \%)\end{array}$ & $\begin{array}{l}\text { often } 2(2.7 \%) \\
\text { rarely } 3(4.1 \%) \\
\text { never } 68(93.2 \%)\end{array}$ \\
\hline šeštarnè & \multicolumn{2}{|l|}{$\begin{array}{l}\text { not specified } 63(86.3 \%) \\
\text { krumpliaratis (gear; wheel) } 9(12.3 \%) \\
\text { krumplis (gear) } 1(1.4 \%)\end{array}$} & $\begin{array}{l}\text { often } 3(4.1 \%) \\
\text { rarely } 2(2.7 \%) \\
\text { never } 68(93.2 \%)\end{array}$ \\
\hline $\begin{array}{l}\text { šosiejai, šoseja } \\
\text { šosè, šosiejus - highway (Boruta et } \\
\text { al. 1936) }\end{array}$ & $\begin{array}{l}\text { not specified } 69(94.5 \%) \\
\text { vairuotojas (driver) } 1(1.4 \%) \\
\text { kelias (road) } 1(1.4 \%)\end{array}$ & $\begin{array}{l}\text { sijos (beams) } 1(1.4 \%) \\
\text { plentas (highway) } 1(1.4 \%)\end{array}$ & \begin{tabular}{|l|} 
often $0(0 \%)$ \\
rarely $0(0 \%)$ \\
never $73(100 \%)$
\end{tabular} \\
\hline tavorai & $\begin{array}{l}\text { not specified } 50(68.5 \%) \\
\text { prekés (goods) } 17(23.3 \%) \\
\text { daiktai (objects) } 1(1.4 \%) \\
\text { produktai (products) } 1(1.4 \%)\end{array}$ & $\begin{array}{l}\text { atitvarai (barriers) } 1(1.4 \%) \\
\text { kraitis (dowry) } 1(1.4 \%) \\
\text { pirkiniai (purchase) } 1(1.4 \%) \\
\text { lauktuves (presents) } 1(1.4 \%)\end{array}$ & $\begin{array}{l}\text { often } 0(0 \%) \\
\text { rarely } 3(4.1 \%) \\
\text { never } 70(95.9 \%)\end{array}$ \\
\hline trambleris & \multicolumn{2}{|l|}{$\begin{array}{l}\text { not specified } 69(94.5 \%) \\
\text { sunkvežimis (truck) 2(2.7\%) } \\
\text { skriejikas (crank)1 (1.4\%) } \\
\text { skirstytuvas (distributor)1 (1.4\%) }\end{array}$} & $\begin{array}{l}\text { often } 0(0 \%) \\
\text { rarely } 0(0 \%) \\
\text { never } 73(100 \%)\end{array}$ \\
\hline
\end{tabular}

\section{The evaluation of the exchange of foreign words by their quivalents, and the environment of usage}

Several statements assisted in determining the respondents' approach to the exchange of foreign words into their Lithuanian equivalents: "I approve, that foreign words should be changed by their Lithuanian equivalents" ("Approve"), "I disapprove it, all foreign words should be left in the Lithuanian language" ("Disapprove"), "Only some of the foreign words should be changed by their Lithuanian equivalents" ("Partly"), and "No opinion" (Figure 1).

Vaicekauskienè (2008) pointed out that "extreme purism for the normative Lithuanian linguistics is not and has not ever been inherent". Transport management students underlined the possibility to use already existing international words instead of looking for the Lithuanian equivalents of foreign words ("international words could stay as they are"); the equivalents should be clear and identify the concept in an accurate way ("equivalents of foreign words are sometimes completely incomprehensible and difficult to use"). According to the respondents, the foreign words should be changed by their equivalents: "In order to preserve the identity of the language, we should change the foreign words"; "To my mind, for the majority of Lithuanians, not only for me, many foreign words are just confusing".

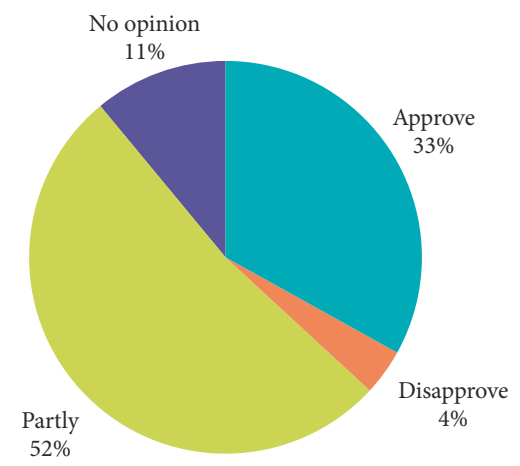

Figure 1. The results of question "What is your oppinion to changing foreign words by their Lithuanian equivalents?"

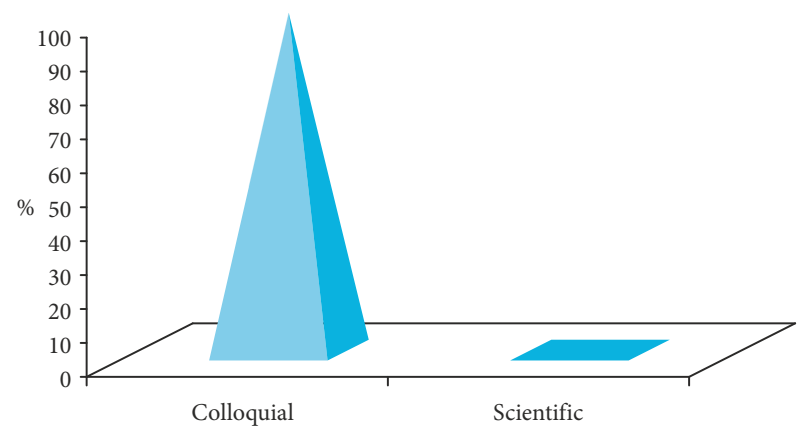

Figure 2. The results of the answers to the question "In which language style do you use the presented foreign words?" 
The results of the answers to the guestion "In which language style do you use the presented foreign words?" show (Figure 2), that foreign words completely disappeared from the scientific language of transport, still remaining only in the colloquial language style of the respondents.

\section{Conclusions}

1. At the end of the 19th century and the first half of the 20th century, the linguists in Lithuania emphasized the importance of the language purification. Lithuanian linguists (K. Būga, P. Skardžius, etc.) put great effort in laying the basis for the loanwords investigation and classification (vocabularies of slavic, german loanwords, and other languages compiled). The first works of lexicography, systematically managing the words of foreign origin, as well as the first Lithuanian dictionary of international words, appeared. These and other works influenced a stronger base for better differentiation of loanwords and establishment of their status in the official language.

2. The majority of the respondents are aware of the foreign words adyna, naždako popierius, relsai, tavorai, resorai, blèta, šeštarne, stacija as the following equivalents: valanda (hour) (38.4\%), švitrinis popierius (abrasive paper) (32.9\%), (geležinkelio) begiai (rails) (32.9\%), prekès (goods) (23.3\%), lingès (springs) (19.2\%), skarda (sheet) (15\%), krumpliaratis (gear) (12.3\%), stotis (station) (11\%).

3. Some of foreign words now have another meaning than in the analysed publications. $30.1 \%$ of the respondents frequently use the foreign word bosas. The data in Table 2 show that students do not know the meanings of the word bosas, as defined in Šlapelis (1907), Boruta et al. (1936). The foreign word bosas, taken from the English language, meaning "chief", "head", has been introduced in Lemchenas (1951) and is still being used. $31.5 \%$ of the respondents use the word karbas, meaning "carburattor". The method of reducing words is used for creating a modern jargon (more for comparison: $a k u$ muliatorius $\rightarrow$ akūmas, benzinas $\rightarrow$ benzas).

4. The frequency of usage of the words analysed is either small or the respondents do not use them at all. These foreign words (in the meanings, which they had during the considered period) are still used by the students: resorai $(8.2 \%)$, naždako popierius $(6.8 \%)$, relsai $(6.8 \%)$, pasažieras $(4.1 \%)$, šeštarne (4.1\%). The respondents totally abandoned the following foreign words: bertainis; kreismeselis; šosiejai, šoseja; trambleris (100\% of the respondents answered "Never").

5. The analysed foreign words, still used by students in their colloquial language, have completely dissapeared from the scientific language.

6. There are foreign words of transport (i.e.: relsai, resorai) and other technical areas, as well as economics (i.e.: kerneris, šeštarné, trambleris, tavorai) in the analysed transport publications of that period.
7. It can be stated that old foreign words are the inheritance of the past, not quite forgotten, a part of our national heritage, assisting in restoring the authenticity of a particular period in Lithuania.

\section{References}

Balčiūnienė, A. 2012. Klaipėdos krašto liuteroniškų kapinių paminkliniai įrašai lingvistiniu aspektu [Tombstone inscriptions in Klaipeda region Lutheran cemeteries: a linguistic viewpoint], Acta Historica Universitatis Klaipedensis 25: 62-76 (in Lithuanian). https://doi.org/10.15181/ahuk.v25i0.313

Boruta, K.; Čepènas, P.; Sirutytė-Čepenienė, A. 1936. Tarptautinių žodžių žodynas. Klaipèda: „Ryto“ bendrovès spaustuvè. 1064 p. (in Lithuanian).

Bufienè, G.; Grigas, K.; Kudirkienè, L.; Kašètienė, R.; Zaikauskienè, D. 2008. Lietuviu patarlès ir priežodžiai. 2 tomas. Vilnius: Lietuvių literatūros ir tautosakos institutas. 830 p. (in Lithuanian).

Čepienè, N. 2006. Lietuviu kalbos germanizmai ir ju fonetinès ypatybès. Vilnius: Lietuvių kalbos institutas. 364 p. (in Lithuanian).

KAM. 1919. Instrukcijos karo automobiliu šoferiams. Krašto apsaugos ministerijos (KAM) Literatūros dalies leidinys. Kaunas: Lietuvos valstybės spaustuvè. 57 p. (in Lithuanian).

Katalynaitè, R.; Klibavičius, A.; Kvietkauskas, V.; Lapinskas, R.; Paliulis, G. 1995. Penkiakalbis automobilių terminų žodynas. Vilnius: Keturi ratai. 452 p. (in Lithuanian, Russian, English, German and French).

Kaulakienè, A. 2009. Lietuviu fizikos terminijos raida. Vilnius: Technika. 438 p. (in Lithuanian). https://doi.org/10.3846/1589-M

Keinys, S. (Ed.). 2012. Dabartinès lietuvių kalbos žodynas. 7-as leidimas. Vilnius: Lietuvių kalbos institutas. 969 p. (in Lithuanian).

Končius, I. 1919. Fizika: fizikos vadovèis gimnazijoms. Rankraštis (in Lithuanian).

Križinauskas, J. 2009. Vokiečių-lietuvių kalbų žodynas. Vilnius: TEV. 719 p. (in Lithuanian and German).

Lemchenas, Ch. (Ed.). 1951. Tarptautiniu žodžiu žodynas. Valstybinè politinès ir mokslinès literatūros leidykla. 727 p. (in Lithuanian).

Lemchenas, Ch.; Macaitis, J. 2005. Rusu-lietuviu kalbu žodynas. Vilnius: Mokslo ir enciklopedijų leidybos centras. 938 p. (in Lithuanian and Russian).

Lietuvių-prancūzų žodynas. 2017. Available from Internet: http:// www.zodynas.lt/zodynai/lietuviu-prancuzu (in Lithuanian and French).

M. ir S. 1923. Svetimu ir tarptautišku žodžių žodynèlis. Šiauliai: Vilties draugija. 84 p. (in Lithuanian).

Mikulènienè, D.; Dvylyte, A. 2013. Kalbos patarimai 4. Leksika. Skoliniu vartojimas (leksikos skoliniu sąrašas ir senujų svetimybiu sąrašas). 2-as leidimas. Vilnius: Mokslo ir enciklopedijų leidybos centras. 96 p. (in Lithuanian).

Mikulènienè, D.; Dvylyte, A. 2005. Kalbos patarimai 4. Leksika. Skoliniu vartojimas. 21-as leidimas. Vilnius: Mokslo ir enciklopedijų leidybos institutas. 118 p. (in Lithuanian).

Milcziauckas, P. 1886. Důnos jieszkoczei, Auszra 3: 87-90 (in Lithuanian).

Nedarykite, kas nedarytina. 1924. Lietuvos žinios 181: 1-1 (in Lithuanian).

Negyvụjų laivas. 1932. Aušrelè 18: 8-8. (in Lithuanian).

Norkus, J. 1924. Svetimu ir nesuprantamy žodžių žodynèlis. Kaunas: Vaivos bendrovè. 95 p. (in Lithuanian). 
Olševskis, V. 1899. Garo mašinos ir geležkeliai. Tilžè: Ūkininkas. 48 p. (in Lithuanian).

Petrètienè, A.; Tomaševskis, R. 2011. Leidinio „Instrukcijos karo automobilių šoferiams" (1919 m.) kalba [Language in publication „,instructions for military vehicles chauffeurs” (1919)], Santalka: Filologija, Edukologija / Coactivity: Philology, Educology 19(2): 168-180 (in Lithuanian).

https://doi.org/10.3846/cpe.2011.18

Šlapelis, J. 1907. Svetimu ir nesuprantamų žodžiu žodynèlis: skaitytojams palengvinimas. Tilžè: E. Jagomasto spaustuvè. 110 p. (in Lithuanian).

Trys Telšių kepyklos. 1931. Žemaičiu balsas 7: 2-2 (in Lithuanian).

Vaicekauskienè, L. 2008. Preskriptyvumas ir deskriptyvumas (skolinių) norminimo politikoje, Darbai ir dienos / Deeds and Days 50: 31-41 (in Lithuanian).

Valančius, M. 1867. Patarles zemajcziu. Tilžè. 52 p. (in Lithuanian).

Vileišis, P. 1903. Irankis pagerinimui ir sutaisimui šoseju ir paprastuju kelų. Tilžè. 31 p. (in Lithuanian).

VLKK. 2017. Lietuvos Respublikos terminu bankas. Valstybinè lietuvių kalbos komisija (VLKK) [State Commission of the Lithuanian Language]. Available from Internet: http://terminai.vlkk.lt (in Lithuanian).

Zinkevičius, Z. 1992. Bendrinès kalbos iškilimas. Vilnius: Mokslo ir enciklopedijų leidykla. 350 p. (in Lithuanian).

Žitkute, A. 1996. Vokiečiu-lietuviu, lietuviu-vokiečiu kalbu automobiliu terminų žodynas. Vilnius: Mokslo ir enciklopedijų leidykla. 360 p. (in Lithuanian and German). 